Cite this: J. Mater. Chem. A, 2013, 1, 6407

Received 23rd January 2013 Accepted 27th March 2013

DOI: $10.1039 /$ c3ta10360a

www.rsc.org/MaterialsA
View Article Online

View Journal / View Issue

\title{
Solar hydrogen evolution using metal-free photocatalytic polymeric carbon nitride/CulnS 2 composites as photocathodes
}

\begin{abstract}
Florent Yang, ${ }^{\text {*a }}$ Vadym Kuznietsov, ${ }^{\text {a }}$ Michael Lublow, ${ }^{\text {b }}$ Christoph Merschjann, ${ }^{\text {ac }}$ Alexander Steigert, ${ }^{a}$ Joachim Klaer, ${ }^{d}$ Arne Thomas $^{\mathrm{e}}$ and Thomas Schedel-Niedrig ${ }^{a}$

Polymeric carbon nitride $\left(\mathrm{g}-\mathrm{C}_{3} \mathrm{~N}_{4}\right)$ films were synthesized on polycrystalline semiconductor CulnS 2 chalcopyrite thin film electrodes by thermal polycondensation and were investigated as photocathodes for the hydrogen evolution reaction (HER) under photoelectrochemical conditions. The composite photocathode materials were compared to $\mathrm{g}-\mathrm{C}_{3} \mathrm{~N}_{4}$ powders and were characterized with grazing incidence X-ray diffraction and X-ray photoemission spectroscopy as well as Fourier transform infrared and Raman spectroscopies. Surface modification of polycrystalline Culn $\mathrm{S}_{2}$ semiconducting thin films with photocatalytically active $\mathrm{g}-\mathrm{C}_{3} \mathrm{~N}_{4}$ films revealed structural and chemical properties corresponding to the properties of $\mathrm{g}-\mathrm{C}_{3} \mathrm{~N}_{4}$ powders. The $\mathrm{g}-\mathrm{C}_{3} \mathrm{~N}_{4} / \mathrm{CulnS}_{2}$ composite photocathode material generates a cathodic photocurrent at potentials up to $+0.36 \mathrm{~V}$ vs. $\mathrm{RHE}$ in $0.1 \mathrm{M} \mathrm{H}_{2} \mathrm{SO}_{4}$ aqueous solution $(\mathrm{pH} 1)$, which corresponds to $\mathrm{a}+0.15 \mathrm{~V}$ higher onset potential of cathodic photocurrent than the unmodified CulnS $_{2}$ semiconducting thin film photocathodes. The cathodic photocurrent for the modified composite photocathode materials was reduced by almost $60 \%$ at the hydrogen redox potential. However, the photocurrent generated from the $\mathrm{g}-\mathrm{C}_{3} \mathrm{~N}_{4} / \mathrm{CuInS}_{2}$ composite electrode was stable for $22 \mathrm{~h}$. Therefore, the presence of the polymeric $\mathrm{g}-\mathrm{C}_{3} \mathrm{~N}_{4}$ films composed of a network of nanoporous crystallites strongly protects the CulnS $\mathrm{S}_{2}$ semiconducting substrate from degradation and photocorrosion under acidic conditions. Conversion of visible light to hydrogen by photoelectrochemical water splitting can thus be successfully achieved by $\mathrm{g}-\mathrm{C}_{3} \mathrm{~N}_{4}$ films synthesized on polycrystalline CulnS $\mathrm{S}_{2}$ chalcopyrite electrodes.
\end{abstract}

\section{Introduction}

Photocatalytic and photoelectrochemical (PEC) water splitting using semiconductor materials have attracted considerable attention because of the potential to produce $\mathrm{H}_{2}$ from $\mathrm{H}_{2} \mathrm{O}$ by utilizing the abundant solar energy. ${ }^{1}$ One approach to achieve solar-induced water splitting is to employ two photoelectrochemical half-cells, with one cell acting as the photocathode and the other as the photoanode. ${ }^{2}$

For such systems, the use of relatively small band gap materials (i.e., 1.1-1.7 eV) is desired in order to efficiently absorb light in the range of the terrestrial solar spectrum. Simultaneously, the respective positions of the conduction band minimum and

${ }^{a}$ Helmholtz-Zentrum Berlin für Materialien und Energie $\mathrm{GmbH}$, Institut für Heterogene Materialsysteme, Hahn-Meitner-Platz 1, 14109 Berlin, Germany. E-mail: florent. yang@helmholtz-berlin.de; Fax: +49 308062 43199; Tel: +49 30806242175

${ }^{b}$ Leibnitz-Institut für Katalyse - LIKAT, Albert-Einstein-Straße 29a, 18059 Rostock, Germany

'Universität Rostock, Institut für Physik, Universitätsplatz 3, 18055 Rostock, Germany ${ }^{d}$ Helmholtz-Zentrum Berlin für Materialien und Energie GmbH, Institut für Technologie, Hahn-Meitner-Platz 1, 14109 Berlin, Germany

${ }^{e}$ Technische Universität Berlin, Institut für Chemie, Straße des 17. Juni 135, 10623 Berlin, Germany valence band maximum have to be adapted to the standard potentials of $\mathrm{H}_{2}$ and $\mathrm{O}_{2}$ evolution to provide the necessary overall photovoltage $(>1.23 \mathrm{~V})$ required for direct water splitting.

Polycrystalline chalcopyrite thin films have been intensively studied as a material for absorber layers in photovoltaic thin film devices. ${ }^{3}$ Semiconducting chalcopyrite thin film absorbers such as $\mathrm{CuGaSe}_{2}, \mathrm{CuInS}_{2}$, and $\mathrm{Cu}(\mathrm{Ga}, \mathrm{In}) \mathrm{Se}_{2}$ are very attractive candidates for solar-driven water splitting because they have suitable band gap energies ( $c a \cdot 1.0-1.7 \mathrm{eV}),{ }^{4-6}$ and can in principle produce a significant portion of the required photovoltage. Moreover, the fabrication of efficient chalcopyrite thin film absorbers represents a state-of-the-art technology. ${ }^{7}$ According to recent investigations, chalcopyrites can be successfully employed as photocathodes, i.e. for reduction of protons by light-induced photoelectrons. ${ }^{8} \mathrm{CuInS}_{2}$ (CIS), for instance, is a ptype semiconductor with a band gap of $1.5 \mathrm{eV}$ providing large photocarrier densities under illumination.,9 The highest solar energy conversion efficiency of photovoltaic cells based on CIS materials has been reported to be $11.4 \%{ }^{5,9}$ An application for the cathodic half-cell reaction of water splitting, i.e. hydrogen evolution, therefore appears to be possible provided that a stable operation can be achieved upon immersion into an aqueous environment. Upon photoelectrochemical (PEC) water 
splitting, photoexcited electrons move towards the CIS-electrolyte interface to induce the reaction $2 \mathrm{H}_{2} \mathrm{O}+2 \mathrm{e}^{-} \rightarrow \mathrm{H}_{2}+$ $2 \mathrm{OH}^{-}$. A majority of carriers (holes) move towards the backcontact and through the outer circuit to the counter electrode where oxygen evolves. To perform PEC water splitting, the valence band maximum (VBM) and conduction band minimum (CBM) of the semiconductor electrode have to straddle the standard potentials of hydrogen and oxygen evolution [0 and $1.23 \mathrm{~V} v s$. reversible hydrogen electrode (RHE), respectively]. In acidic solutions, as used in our experiments, protons are already present in the electrolyte, and the CIS interface is employed for the evolution of hydrogen by $2 \mathrm{H}^{+}+2 \mathrm{e}^{-} \rightarrow \mathrm{H}_{2}$ while water splitting occurs at the Pt-counter electrode.

To date, to the best of our knowledge, no information has been reported in the literature on the capability of g- $\mathrm{C}_{3} \mathrm{~N}_{4}$ / $\mathrm{CuInS}_{2}$ thin film composites as a photocathode material.

Over the past decade, considerable research efforts have been made to investigate polymeric carbon nitride $\left(\mathrm{g}-\mathrm{C}_{3} \mathrm{~N}_{4}\right)$ due to its specific properties (thermal and chemical stability) predicted by theoretical results. ${ }^{10}$ Although this material has a high band gap of $\sim 2.7 \mathrm{eV}$, as determined by UV/Vis diffuse reflectance measurements, ${ }^{\mathbf{1 1}, \mathbf{1 2}}$ many studies have been extensively performed in growing research fields for applications in photochemistry, photocatalysis, and sustainable chemistry, to name a few. ${ }^{\mathbf{1 3 - 1 5}}$ Very recently, non-precious metal $\mathrm{g}-\mathrm{C}_{3} \mathrm{~N}_{4}$ has attracted increased interest as a potential material for photocatalytic overall water splitting. ${ }^{11}$ Metal-free $\mathrm{g}-\mathrm{C}_{3} \mathrm{~N}_{4}$ was shown to produce both hydrogen and oxygen via water splitting under visible light illumination in the presence of proper sacrificial donor and acceptor materials, respectively. ${ }^{11}$ However, most of the studies have been performed on $\mathrm{g}-\mathrm{C}_{3} \mathrm{~N}_{4}$ powders.

In this study we report the application of polycrystalline $\mathrm{CuInS}_{2}$ thin film semiconducting absorber as a photocathode for the production of $\mathrm{H}_{2}$ from acidic aqueous solutions and we will show that the deposition of $\mathrm{g}-\mathrm{C}_{3} \mathrm{~N}_{4}$ films, achieved by direct synthesis on the $\mathrm{CuInS}_{2}$ substrates, has beneficial effects in both stability and charge carrier kinetics. A schematic illustration of the light converting device based on the heterostructure $\mathrm{g}^{-} \mathrm{C}_{3} \mathrm{~N}_{4} / \mathrm{CuInS} \mathrm{S}_{2}$ composite electrode in acidic aqueous solution is shown in Fig. 1. Most of the blue part of the solar spectrum up to $460 \mathrm{~nm}$ is captured by the $\mathrm{g}-\mathrm{C}_{3} \mathrm{~N}_{4}$ material due to its high bandgap $(2.7 \mathrm{eV})$, while the red portion of the visible light is absorbed by the $\mathrm{CuInS}_{2}$ semiconducting electrode with a smaller band gap $(1.5 \mathrm{~V})$. The synthesis of $\mathrm{g}-\mathrm{C}_{3} \mathrm{~N}_{4}$ materials is carried out by thermal polycondensation from dicyandiamide at a temperature of $550{ }^{\circ} \mathrm{C}$. Structural and chemical properties of g- $\mathrm{C}_{3} \mathrm{~N}_{4}$ materials were investigated using grazing incidence $\mathrm{X}$ ray diffraction (XRD), X-ray photoelectron spectroscopy (XPS), as well as Fourier transform infrared spectroscopy (FTIR) with ATR mode and Raman spectroscopy. It is shown that synthesized $\mathrm{g}-\mathrm{C}_{3} \mathrm{~N}_{4}$ films on p-type $\mathrm{CuInS}_{2}$ substrates, in terms of structural and chemical properties, are corresponding to the properties of $\mathrm{g}-\mathrm{C}_{3} \mathrm{~N}_{4}$ powders. It is thereby proven that the process of dicyandiamide polycondensation is a suitable method for fabrication of $\mathrm{g}-\mathrm{C}_{3} \mathrm{~N}_{4}$ thin films on semiconductor supports. Moreover, the presence of $\mathrm{g}-\mathrm{C}_{3} \mathrm{~N}_{4}$ thin films on $\mathrm{CuInS}_{2}$ electrodes is found to shift the cathodic photocurrent at

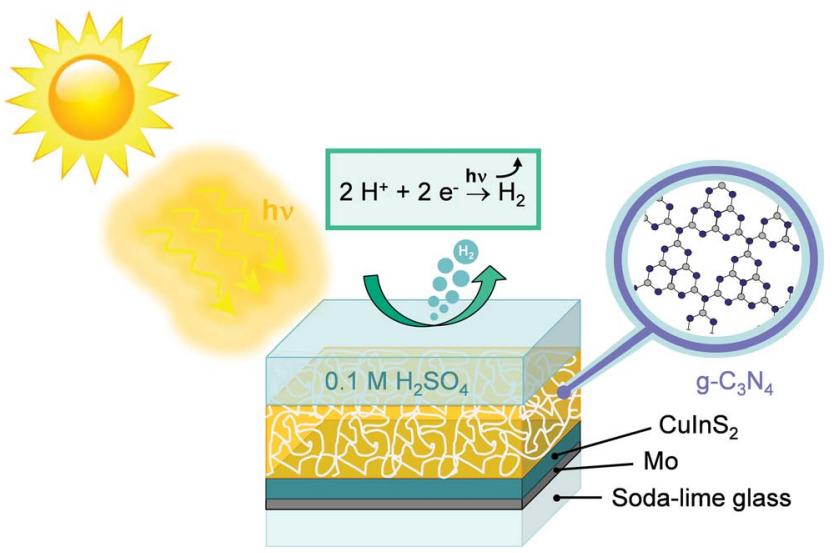

Fig. 1 Schematic of the $\mathrm{g}-\mathrm{C}_{3} \mathrm{~N}_{4} / \mathrm{CuInS}_{2}$ heterostructure in $0.1 \mathrm{M} \mathrm{H}_{2} \mathrm{SO}_{4}$ solution $(\mathrm{pH} 1)$ for conversion of solar energy into chemical energy. The light is incident from above. The blue part of the solar spectrum is absorbed by the $\mathrm{g}-\mathrm{C}_{3} \mathrm{~N}_{4}$ film with a band gap of $\sim 2.7 \mathrm{eV}$, while the red portion reaches the semiconducting CulnS $_{2}$ electrode with a smaller band gap of $\sim 1.5 \mathrm{eV}$.

potentials up to $+0.36 \mathrm{~V}$ vs. RHE in $0.1 \mathrm{M} \mathrm{H}_{2} \mathrm{SO}_{4}$ aqueous solution ( $\mathrm{pH} 1$ ), which corresponds to a $+0.15 \mathrm{~V}$ higher onset potential of the cathodic photocurrent compared to the bare $\mathrm{CuInS}_{2}$ electrodes. Furthermore, it will be shown that the formation of $\mathrm{g}-\mathrm{C}_{3} \mathrm{~N}_{4}$ thin films on $\mathrm{CuInS}_{2}$ electrodes results in long-term stable photocurrent densities, monitored during a $22 \mathrm{~h}$ period upon hydrogen evolution from $\mathrm{H}_{2} \mathrm{SO}_{4}$ containing solutions. The fabrication of $\mathrm{g}-\mathrm{C}_{3} \mathrm{~N}_{4}$ based heterostructures is therefore a promising concept for the conversion of solar energy to chemical energy.

\section{Experimental section}

\section{Preparation of the $\mathrm{g}-\mathrm{C}_{3} \mathrm{~N}_{4} / \mathrm{CuInS}_{2}$ composite photocathode}

Polycrystalline $\mathrm{CuInS}_{2}$ thin films were prepared by sputtering of metal precursors ( $\mathrm{Cu}$ and $\mathrm{In}$ ) followed by sulfurization on sodalime glass substrates coated with Mo layers, as reported previously. ${ }^{5,9}$ To remove the remaining segregated $\mathrm{CuS}$, formed during the process on the surface, the $\mathrm{CuInS}_{2}$ substrates were etched in $10 \% \mathrm{KCN}$ solution for 3 minutes. Device-grade chalcopyrite $\mathrm{CuInS}_{2}$ thin films have been prepared by using the wellknown RTP technique as described in ref. 5 and 9. Dicyandiamide $\left(\mathrm{C}_{2} \mathrm{~N}_{4} \mathrm{H}_{4}\right)$ was supplied by Sigma Aldrich. All other chemical reagents used in this study were analytically pure and used without further purification. Polymeric carbon nitride (g$\mathrm{C}_{3} \mathrm{~N}_{4}$ ) films were synthesized onto p-type semiconducting $\mathrm{CuInS}_{2}$ chalcopyrite substrates by thermal polycondensation of dicyandiamide $\left(\mathrm{C}_{2} \mathrm{~N}_{4} \mathrm{H}_{4}\right)$ powder at a temperature of $550{ }^{\circ} \mathrm{C}$ under an inert nitrogen gas atmosphere. ${ }^{16}$ Dicyandiamide powder was deposited on the $\mathrm{CuInS}_{2}$ chalcopyrite substrates and heated from $25{ }^{\circ} \mathrm{C}$ to $550{ }^{\circ} \mathrm{C}$ at a rate of $50{ }^{\circ} \mathrm{C} \mathrm{min}{ }^{-1}$. After reaching the maximum temperature, the samples were kept at $550{ }^{\circ} \mathrm{C}$ for $10 \mathrm{~min}$ by which the preparation of the $\mathrm{g}-\mathrm{C}_{3} \mathrm{~N}_{4}$ / $\mathrm{CuInS}_{2}$ thin film composite electrodes was completed. Subsequent analyses were carried out immediately after sample preparation. 


\section{Characterization}

Fourier transform infrared (FTIR) spectroscopy with ATR mode and Raman spectroscopy were carried out with FTIR Bruker Equinox 55 and Raman Bruker FRA 106/S spectrometers, respectively, to investigate the vibrational properties of the material. FTIR and Raman spectra were measured with a resolution of 2 and $4 \mathrm{~cm}^{-1}$, respectively.

X-Ray Diffraction (XRD) patterns were measured with a Bruker AXS (D8 Advance) diffractometer by using $\mathrm{Cu} \mathrm{K}_{\alpha}$ radiation $(\lambda=1.5418 \AA)$ to characterize the crystallographic structure of the $\mathrm{g}-\mathrm{C}_{3} \mathrm{~N}_{4}$ material.

X-ray photoelectron spectroscopy (XPS) was performed with a Phoibos spectrometer using a monochromatized $\mathrm{Mg} \mathrm{K}_{\alpha}(h \nu=$ $1253.6 \mathrm{eV}$ ) X-ray radiation source to investigate the chemical and electronic states at the surface. The core level spectra have been deconvoluted by a fitting procedure using Voigt line shapes (combination of Gaussian-Lorentzian functions) after Shirley background subtraction. XPS spectra of the $\mathrm{g}-\mathrm{C}_{3} \mathrm{~N}_{4}$ powder have been multiplied by a factor of five for better clarity.

For UPS measurements, a helium lamp providing the He I line at $h \nu=21.21 \mathrm{eV}$ was used. The secondary electron cutoff region was recorded with a sample bias at $-5 \mathrm{~V}$. An uncertainty error of $\pm 0.1 \mathrm{eV}$ is estimated relative to the spectrum.

Scanning electron microscopy (SEM) was carried out with a LEO GEMINI 1530 scanning electron microscope, with an acceleration voltage of $10 \mathrm{kV}$.

\section{Photoelectrochemical experiments}

Photocurrent measurements were performed using a Biologic potentiostat in a three-electrode configuration. For illumination, a tungsten-iodine (W-I) lamp was used (Fiber Lite MI-150 from Dolan-Jenner Industries) with a light intensity of $100 \mathrm{~mW}$ $\mathrm{cm}^{-2}$ (corresponding to 1 sun, i.e. AM $1.5 \mathrm{G}$ condition). The

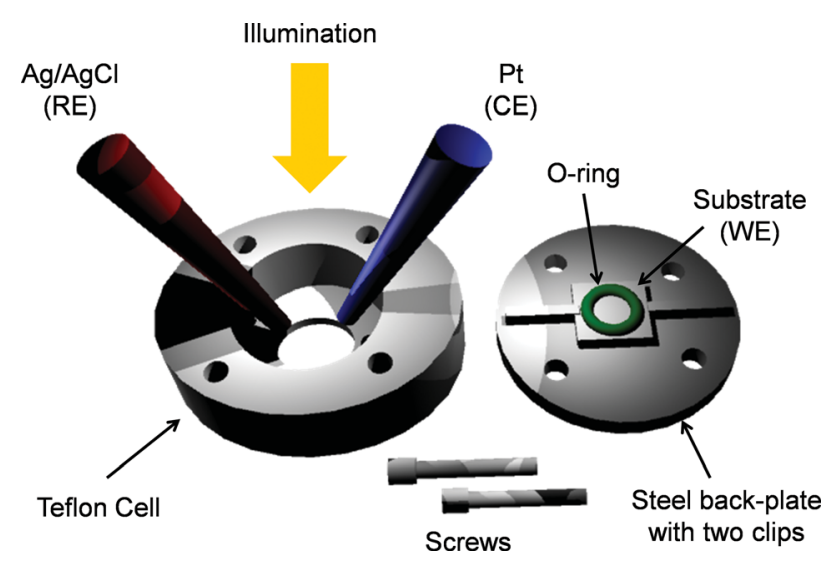

Fig. 2 Scheme of the electrochemical cell, consisting of a typical three electrode system: $\mathrm{g}-\mathrm{C}_{3} \mathrm{~N}_{4} / \mathrm{CulnS}_{2}$ and, respectively, bare $\mathrm{CulnS}_{2}$ substrates were used as working electrodes, a Pt wire as a counter electrode, and an $\mathrm{Ag} / \mathrm{AgCl}$ electrode as a reference electrode. Front contact connection with the substrate was realized by a steel back-plate to which two steel clips, in contact with the surface of the sample, were connected. The simulated AM 1.5 G illumination was incident from the top of the electrochemical cell. The surface area of the working electrode, exposed to the electrolyte, was $0.5 \mathrm{~cm}^{2}$. setup of the electrochemical cell consists of a Teflon cell body and three electrodes, such as a working electrode (as-prepared polycrystalline $\mathrm{CuInS}_{2}$ with and without an additional g- $\mathrm{C}_{3} \mathrm{~N}_{4}$ film), a platinum wire as a counter electrode and a $\mathrm{Ag} / \mathrm{AgCl}$ electrode as a reference electrode, being in contact with saturated $\mathrm{KCl}[0.197 \mathrm{~V}$ vs. normal hydrogen electrode (NHE)]. A $0.1 \mathrm{M}$ sulfuric acid $\left(\mathrm{H}_{2} \mathrm{SO}_{4}\right)$ solution $(\mathrm{pH} 1)$ was used as the electrolyte for the photoelectrochemical investigations. At the edges of the substrates, a part of the film has been removed to reach the Mo layer beneath. A front contact connection between the Mo layer and the steel clips attached to the high-grade steel back-plate of the electrochemical cell was thereby realized. The schematic electrochemical setup is depicted in Fig. 2. Currentpotential measurements were performed in $0.1 \mathrm{M} \mathrm{H}_{2} \mathrm{SO}_{4}$ aqueous solution versus $\mathrm{Ag} / \mathrm{AgCl}$ reference electrode and the potential of the working electrode was continuously incremented at a scan rate of $5 \mathrm{mV} \mathrm{s}^{-1}$ under intermittent illumination with a period of $5 \mathrm{~s}$ each.

\section{Results and discussion}

In Fig. 3, XRD analysis of the $\mathrm{g}-\mathrm{C}_{3} \mathrm{~N}_{4}$ powder as well as the $\mathrm{g}$ $\mathrm{C}_{3} \mathrm{~N}_{4}$ film synthesized on $\mathrm{CuInS}_{2}$ electrodes is shown. Two prominent features are visible: (i) the small peak at $13.1^{\circ}$ corresponds to a lattice distance of $d=0.676 \mathrm{~nm}$ which is related to the in-plane structural packing of nitrogen-linked heptazine units and (ii) the prominent peak at $27.5^{\circ}$ is characteristic of an interplanar stacking distance of aromatic units, as known for the graphite lattice. The stacking distance of the aromatic units is calculated to be $d=0.324 \mathrm{~nm}$. These two peak positions are in good agreement with previously published reports. ${ }^{11,13}$ Comparison of XRD data for the powder and the film proves that the polycondensation process of dicyandiamide results in identical structural properties. Moreover, a comparative investigation with UV/Vis diffuse reflectance and photoluminescence spectra indicates similar optical properties for both the powder and the film (not shown here). For both

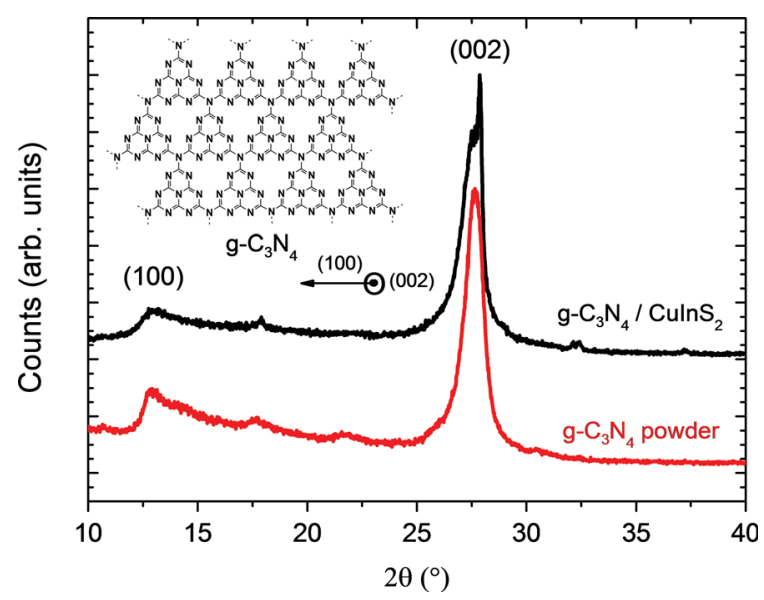

Fig. $3 X R D$ patterns of the $g-C_{3} N_{4}$ powder and a $g-C_{3} N_{4}$ film on the Culn $S_{2}$ semiconducting electrode. Inset: schematic structure of an idealized graphitic carbon nitride network constructed from tri-s-triazine based connection patterns. 
materials the onset of the absorption has been deduced to be $2.7 \mathrm{eV} .{ }^{\mathbf{1 2}}$ These results demonstrate the successful preparation of $\mathrm{g}-\mathrm{C}_{3} \mathrm{~N}_{4}$ films on semiconducting $\mathrm{CuInS}_{2}$ electrodes.

Fig. 4a displays the XPS survey scans of the $\mathrm{g}-\mathrm{C}_{3} \mathrm{~N}_{4}$ powder and a g- $\mathrm{C}_{3} \mathrm{~N}_{4}$ film on the $\mathrm{CuInS}_{2}$ electrode. Core level analysis of $\mathrm{C} 1 \mathrm{~s}$ and $\mathrm{N} 1 \mathrm{~s}$, respectively, are shown in Fig. $4 \mathrm{~b}$ and $4 \mathrm{c}$. The survey scans indicate the presence of carbon, nitrogen, and oxygen in the $\mathrm{g}-\mathrm{C}_{3} \mathrm{~N}_{4}$ powder as well as in the $\mathrm{g}-\mathrm{C}_{3} \mathrm{~N}_{4}$ film. As reported earlier, oxygen contributions result from the exposure of the samples to ambient atmosphere and can be removed from the surface by an appropriate annealing process. ${ }^{17}$ The inset in Fig. 4a shows the onset of secondary electrons upon excitation with He I. The determination of the work function $(\Phi)$ for the $\mathrm{g}-\mathrm{C}_{3} \mathrm{~N}_{4}$ film on CuInS $\mathrm{S}_{2}$ substrates is deduced graphically from the linear extrapolation of the secondary electron cutoff edge to the background emission intensity. The $\mathrm{g}-\mathrm{C}_{3} \mathrm{~N}_{4}$ modified CuInS $\mathrm{S}_{2}$ electrode shows a work function of $\Phi=4.3(1) \mathrm{eV}$ with a remaining small surface oxide layer after the PEC performance testing. Post-thermal treatment up to $300{ }^{\circ} \mathrm{C}$ removes this surface oxide and the work function decreases to 4.0 (1) eV (not shown here; see ref. 17). Unmodified polycrystalline $\mathrm{CuInS}_{2}$ is characterized by a work function of $\Phi=5.5$ (1) eV. The difference in the respective values for $\Phi$ between the g- $\mathrm{C}_{3} \mathrm{~N}_{4}$ film on $\mathrm{CuInS}_{2}$ and the unmodified $\mathrm{CuInS}_{2}$ substrate induces a space charge region and, hence, an electric field at the interface leading to charge carrier separation under illumination.

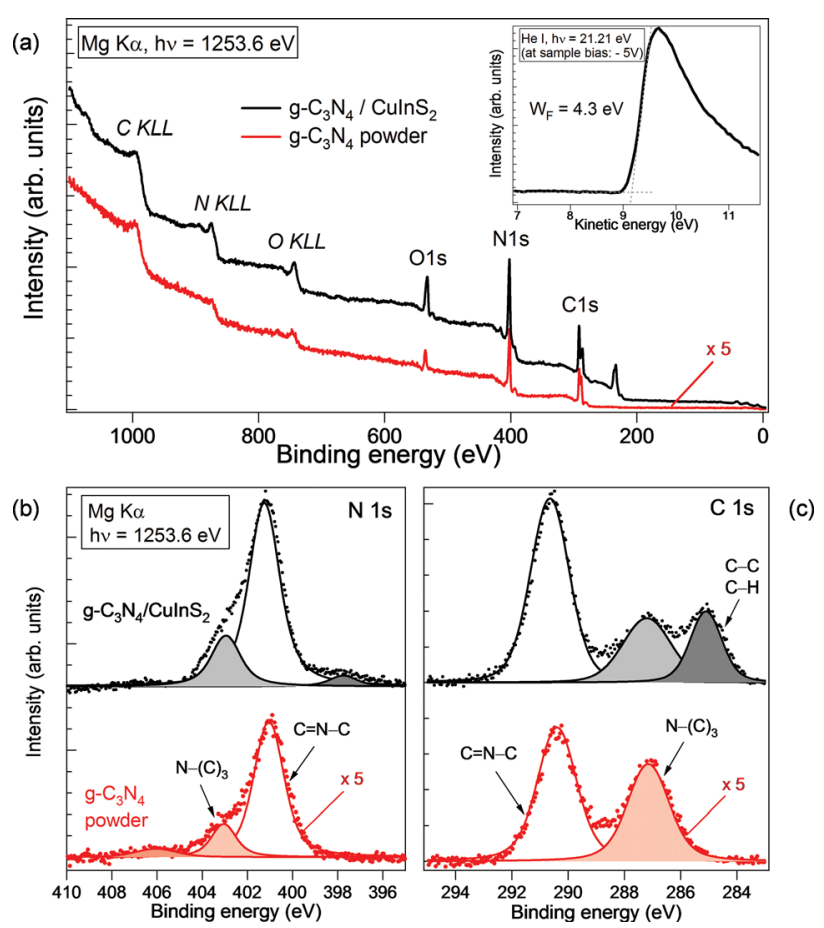

Fig. 4 XPS spectra of the $\mathrm{g}-\mathrm{C}_{3} \mathrm{~N}_{4}$ powder (data shown in red) and a $\mathrm{g}-\mathrm{C}_{3} \mathrm{~N}_{4}$ film on the CulnS 2 electrode (data shown in black): (a) survey spectra, (b) $C$ is core level spectra, and (c) N 1s core level spectra. The C 1s and N 1s spectra were fitted with a Voigt function (convolution of Gaussian-Lorentzian sum functions) after Shirley background subtraction. The inset in (a) shows the secondary electron cutoff edge of the $\mathrm{g}-\mathrm{C}_{3} \mathrm{~N}_{4}$ film on Culns 2 .
High-resolution XPS of the C 1s core level spectra of the g$\mathrm{C}_{3} \mathrm{~N}_{4}$ film synthesized on $\mathrm{CuInS}_{2}$ chalcopyrite substrates reveals three main components. The peak at lower binding energy (BE), centered at $285.1 \mathrm{eV}$, can be attributed to carbon contamination, i.e. $\mathrm{C}-\mathrm{C}, \mathrm{C}-\mathrm{H}$, and/or $\mathrm{C}=\mathrm{C}$ bonds. The two other components at higher $\mathrm{BE}$ at 287.2 and $290.4 \mathrm{eV}$, respectively, are also observable on the $\mathrm{C}$ 1s core level spectrum of the $\mathrm{g}-\mathrm{C}_{3} \mathrm{~N}_{4}$ powder. The $\mathrm{g}-\mathrm{C}_{3} \mathrm{~N}_{4}$ powder only reveals these two peaks, indicating no contamination of aliphatic carbons. The main prominent peak at $290.4 \mathrm{eV}$ is attributed to $\mathrm{sp}^{2}$ carbon-nitrogen bondings of the aromatic ring system -i.e. the $s$-triazine unit pyridine-like structure. ${ }^{17}$ The peak at lower $\mathrm{BE}$ at $287.2 \mathrm{eV}$ is assigned to tertiary nitrogen $\mathrm{N}-(\mathrm{C})_{3}$ groups, i.e. nitrogen trigonally bonded to three $\mathrm{sp}^{2}$ carbon atoms in the $\mathrm{C}-\mathrm{N}$ network (graphitic-like nitrogen structure).

The $\mathrm{N}$ 1s core level spectra show a broad peak centered at $401.2 \mathrm{eV}$ with a shoulder at higher BE. Deconvolution of the data for the $\mathrm{g}-\mathrm{C}_{3} \mathrm{~N}_{4}$ powder reveals contributions of three peaks at 401.1, 403 and $406 \mathrm{eV}$, respectively. The small peak at $406 \mathrm{eV}$ can be attributed to residual nitrite-like $\left(\mathrm{NO}_{2}\right)$ groups at the surface/near-surface region. In the case of the $\mathrm{g}-\mathrm{C}_{3} \mathrm{~N}_{4}$ film on $\mathrm{CuInS}_{2}$ chalcopyrite substrates, a further contribution at lower $\mathrm{BE}$ at $397.8 \mathrm{eV}$ can be observed. The dominant nitrogen peak at $401.1 \mathrm{eV}$ is attributed to nitrogen atoms in an $\mathrm{sp}^{2}$-configuration and bonded to two carbon atoms ( $s$-triazine rings, pyridine-like nitrogen atoms). The other peak at higher $\mathrm{BE}$ at $403 \mathrm{eV}$ is ascribed to tertiary nitrogen $\mathrm{N}-(\mathrm{C})_{3}$ groups, i.e. nitrogen trigonally bonded to three $\mathrm{sp}^{2}$ carbon atoms in the $\mathrm{C}-\mathrm{N}$ network (bridge, graphitic-like nitrogen structure). Here again, the $\mathrm{N} 1 \mathrm{~s}$ core levels of the $\mathrm{g}-\mathrm{C}_{3} \mathrm{~N}_{4}$ film on $\mathrm{CuInS}_{2}$ substrates are in good agreement with those of the $\mathrm{g}-\mathrm{C}_{3} \mathrm{~N}_{4}$ powder. The region at 401$403 \mathrm{eV}$ is generally referred to as quaternary nitrogen, i.e. as "graphitic" nitrogen when the nitrogen atom is incorporated into the graphene layer, replacing therein a carbon atom. ${ }^{\mathbf{1 8}}$

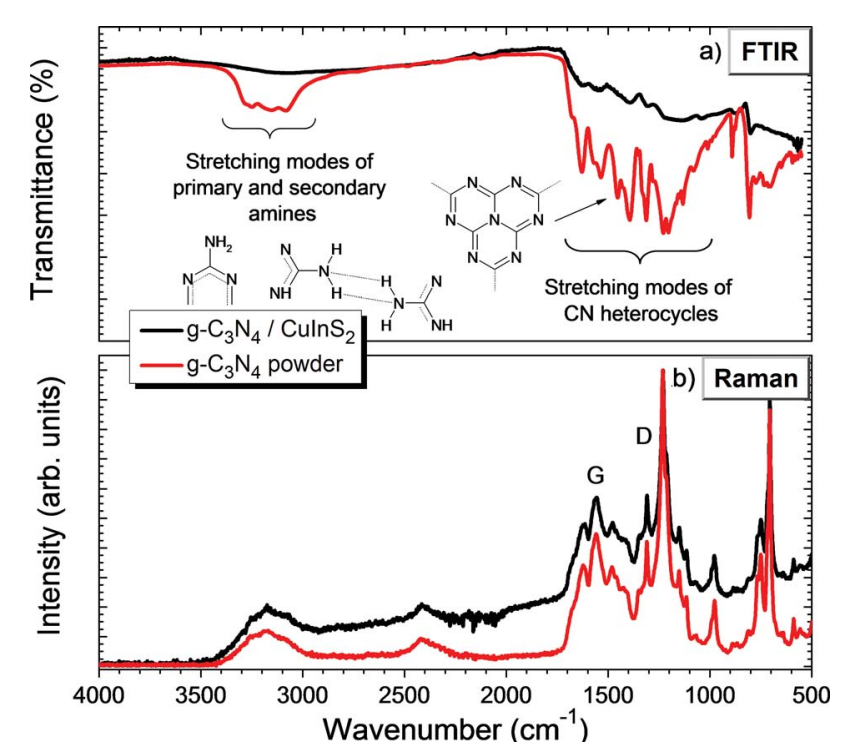

Fig. 5 (a) FTIR spectra and (b) Raman spectra of the $\mathrm{g}-\mathrm{C}_{3} \mathrm{~N}_{4}$ powder (red curve) and a $\mathrm{g}-\mathrm{C}_{3} \mathrm{~N}_{4}$ film on CulnS $\mathrm{S}_{2}$ (black curve). 
Fig. 5 depicts the (a) FTIR and (b) Raman spectra of the g$\mathrm{C}_{3} \mathrm{~N}_{4}$ powder and a g- $\mathrm{C}_{3} \mathrm{~N}_{4}$ film on $\mathrm{CuInS}_{2}$, respectively. As expected, FTIR and Raman spectra of both the $g-\mathrm{C}_{3} \mathrm{~N}_{4}$ powder and the $\mathrm{g}-\mathrm{C}_{3} \mathrm{~N}_{4}$ film on $\mathrm{CuInS}_{2}$ are quite similar, indicating that the $\mathrm{g}-\mathrm{C}_{3} \mathrm{~N}_{4}$ film prepared on the $\mathrm{CuInS} \mathrm{I}_{2}$ chalcopyrite electrode presents identical vibrational modes as the $\mathrm{g}-\mathrm{C}_{3} \mathrm{~N}_{4}$ powder. FTIR and Raman spectra are in good agreement with previously reported data. ${ }^{19-23}$

In the FTIR spectrum of the $\mathrm{g}-\mathrm{C}_{3} \mathrm{~N}_{4}$ powder, the broad set of intense peaks between 900 and $1700 \mathrm{~cm}^{-1}$ is characteristic of $s$ triazine derivatives' vibrational modes like $\mathrm{C}-\mathrm{N}$ and $\mathrm{C}=\mathrm{N}$ stretching modes, ${ }^{20}$ indicating that nitrogen is chemically bonded to carbon in the $\mathrm{g}-\mathrm{C}_{3} \mathrm{~N}_{4}$ material. The peak at $805 \mathrm{~cm}^{-1}$ is assigned to the breathing vibrational modes of $s$-triazine units. ${ }^{21,24,25}$ At higher wavenumbers, another broad set of low intensity peaks between 3000 and $3300 \mathrm{~cm}^{-1}$ can be observed and is attributed to the presence of the stretching vibrational modes of primary $\left(-\mathrm{NH}_{2}\right)$ and secondary $(=\mathrm{N}-\mathrm{H})$ amines suggesting the hydrogenation of some nitrogen atoms in the $\mathrm{g}-\mathrm{C}_{3} \mathrm{~N}_{4}$ material. ${ }^{19,25,26}$ These peaks are also associated with amine bridges. Moreover, a small absorption peak at $2157 \mathrm{~cm}^{-1}$ can be noticed, and is assigned to the cyano terminal group $(\mathrm{C} \equiv \mathrm{N})$ and cumulated double bond $\left(-\mathrm{N}=\mathrm{C}=\mathrm{N}-\right.$ and similar species) in the powder. ${ }^{27}$

Raman spectra of both the $\mathrm{g}-\mathrm{C}_{3} \mathrm{~N}_{4}$ powder and the $\mathrm{g}-\mathrm{C}_{3} \mathrm{~N}_{4}$ film are quite similar, and show two major broad set of peaks. The two peaks at $\sim 1370$ and $\sim 1570 \mathrm{~cm}^{-1}$ are attributed to the D (for disorder) and G (for graphite) peaks, respectively, which are related to $\mathrm{sp}^{2}$ carbon materials. ${ }^{22,28}$ At higher wavenumbers, two further broad peaks of low intensity can be observed and are characteristic of the second-order Raman features of D and G peaks, respectively, which arise from overtones of modes with "in-plane" atomic displacements. ${ }^{22,29}$ A further set of peaks is observable at lower wavenumbers, indicating the lattice vibrational and the internal modes, respectively.

In Fig. 6, the surface morphology of (a) the $\mathrm{CuInS}_{2}$ chalcopyrite electrode and (b) the g- $\mathrm{C}_{3} \mathrm{~N}_{4}$ film deposited on $\mathrm{CuInS}_{2}$ is investigated by SEM. The top view SEM micrograph in Fig. 6a indicates that the $\mathrm{CuInS}_{2}$ film has a dense and rough surface, which consists of compact agglomerates of angular-shaped crystallites. From the cross-sectional SEM micrograph of the corresponding $\mathrm{CuInS}_{2}$ electrode a film thickness of $2-3 \mu \mathrm{m}$ can be deduced.

The surface morphology of the $\mathrm{g}-\mathrm{C}_{3} \mathrm{~N}_{4}$ film is observed to be highly porous consisting of craters and ditches on the $\mu \mathrm{m}$ scale (see Fig. 6b, upper SEM image). The thickness of the g- $\mathrm{C}_{3} \mathrm{~N}_{4}$ film is typically in the range of $80-100 \mu \mathrm{m}$, as can be observed on the cross-sectional micrograph (Fig. 6b, lower SEM image). As shown in the inset of the cross-sectional micrograph in Fig. 6b, the deposition of the $\mathrm{g}-\mathrm{C}_{3} \mathrm{~N}_{4}$ film does not result in a homogeneous coverage of the CuInS 2 surface. However, due to its high porosity, which realizes a large surface area, the modified $\mathrm{CuInS}_{2}$ electrode is promising as a photocathode material since a large surface area can considerably improve the photoelectrochemical performance. Additionally, photographs of the measured $\mathrm{CuInS}_{2}$ chalcopyrite and the $\mathrm{g}-\mathrm{C}_{3} \mathrm{~N}_{4} / \mathrm{CuInS}_{2}$ composite electrodes are inserted on the upper micrograph of the respective SEM images. One can observe with the naked eye the color changes of the electrode surface from dark-grey to a)
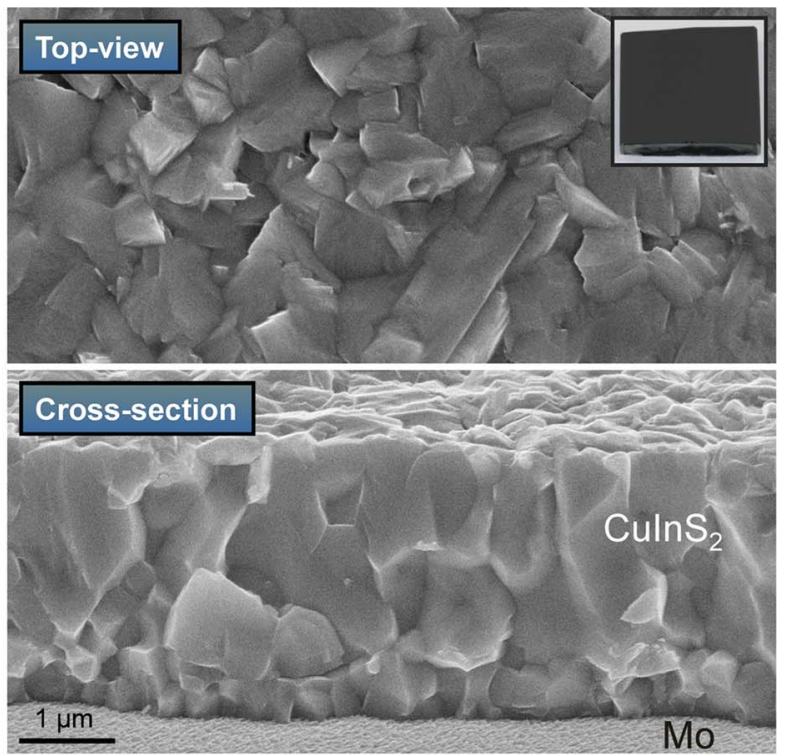

b)
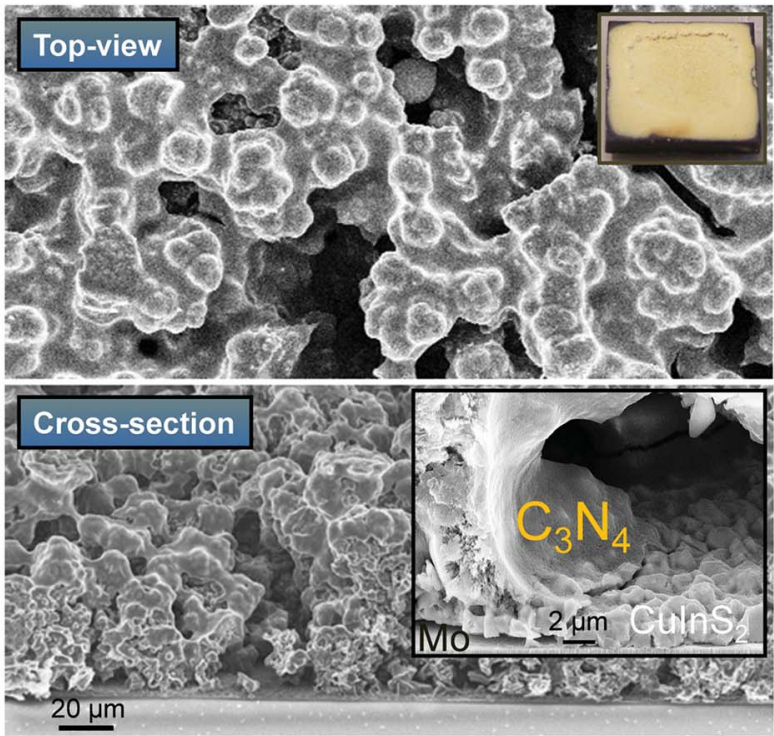

Fig. 6 Surface morphology of the (a) $\mathrm{CulnS}_{2}$ electrode and (b) $\mathrm{g}-\mathrm{C}_{3} \mathrm{~N}_{4}$ film deposited on the CulnS $\mathrm{S}_{2}$ electrode investigated by SEM measurements. Upper and lower micrographs represent the top view and cross-section of CulnS $\mathrm{S}_{2}$ and the $\mathrm{g}-\mathrm{C}_{3} \mathrm{~N}_{4} / \mathrm{CuInS}_{2}$ heterosystem, respectively. The inset in the lower micrograph (b) of the $\mathrm{g}-\mathrm{C}_{3} \mathrm{~N}_{4} /$ CulnS $\mathrm{S}_{2}$ electrode depicts a magnification of the cross-section. Additionally, the photographs of the measured CulnS $_{2}$ and $\mathrm{g}-\mathrm{C}_{3} \mathrm{~N}_{4} /$ CulnS 2 composite electrodes are shown as insets of the respective upper micrographs.

yellow, which indicates good coverage of the $\mathrm{CuInS}_{2}$ electrode by $\mathrm{g}-\mathrm{C}_{3} \mathrm{~N}_{4}$ films.

Current density-potential curves of the bare $\mathrm{CuInS}_{2}$ electrode and $\mathrm{g}-\mathrm{C}_{3} \mathrm{~N}_{4}$ on the $\mathrm{CuInS}_{2}$ electrode immersed in $0.1 \mathrm{M}$ $\mathrm{H}_{2} \mathrm{SO}_{4}$ aqueous solution under intermittent light irradiation of 1 sun, are shown in Fig. 7. Additionally, the typical cathodic polarization curves of both $\mathrm{CuInS}_{2}$ and g- $\mathrm{C}_{3} \mathrm{~N}_{4}$ modified $\mathrm{CuInS}_{2}$ electrodes in the dark (solid line) and under light irradiation of 1 sun (dash-dotted line), respectively, are also presented in Fig. 7. The potential was swept at a scan rate of $5 \mathrm{mV} \mathrm{s}^{-1}$ towards more positive potentials. The unmodified $\mathrm{CuInS}_{2}$ electrode reveals a current density of about $50 \mu \mathrm{A} \mathrm{cm}^{-2}$ at an 


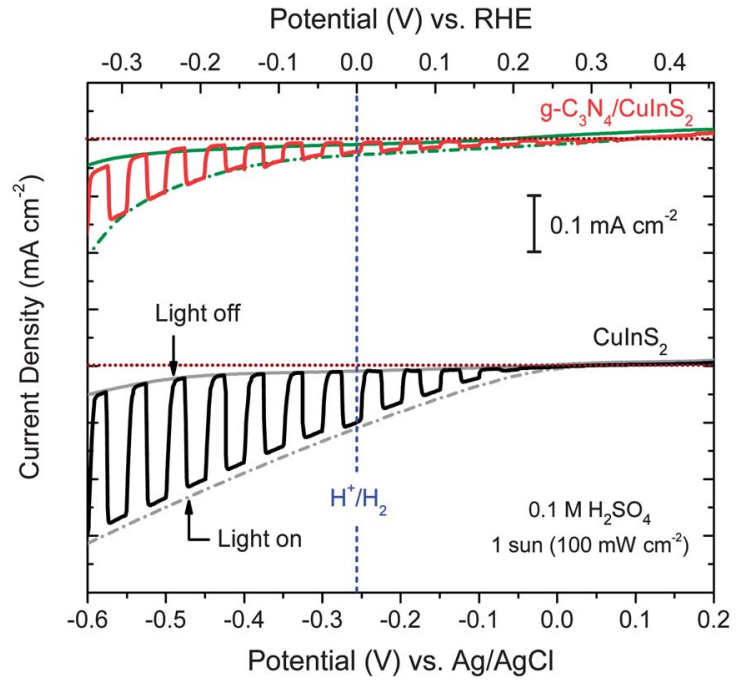

Fig. 7 Current-potential ( $J-E$ ) curves of CulnS $S_{2}$ (black curve) and g- $\mathrm{C}_{3} \mathrm{~N}_{4} / C$ InnS electrodes (red curve), respectively, in $0.1 \mathrm{M} \mathrm{H}_{2} \mathrm{SO}_{4}$ aqueous solution ( $\mathrm{pH} 1$ ) under intermittent solar-simulated irradiation of 1 sun conditions ( 1 sun $=$ AM 1.5 G condition $=100 \mathrm{~mW} \mathrm{~cm}^{-2}$ ). Additionally, the $J-E$ curves in the dark (solid lines) and under illumination of 1 sun (dash-dotted lines) are also shown. The potential was swept from -0.6 to $0.2 \mathrm{~V}$ vs. $\mathrm{Ag} / \mathrm{AgCl}$ reference electrode at a scan rate of 5 $\mathrm{mV} \mathrm{s}^{-1}$ (anodic direction). The respective curves have been shifted vertically for clarity. The $x$-axes are indicated by the dotted lines.

applied potential of $-0.6 \mathrm{~V}_{\mathrm{Ag} / \mathrm{AgCl}}$ in the dark. Under illumination of 1 sun, a cathodic photocurrent density of about $-0.3 \mathrm{~mA}$ $\mathrm{cm}^{-2}$ is reached, corresponding to a net photocurrent density of $\sim 250 \mu \mathrm{A} \mathrm{cm} \mathrm{cm}^{-2}$. This result emphasizes the applicability of $\mathrm{CuInS}_{2}$ as a hydrogen evolving photocathode.

Many electrochemical studies on chalcopyrites $\left(\mathrm{CuFeS}_{2}\right.$, $\mathrm{CuInS}_{2}, \mathrm{CuGaSe}_{2}, \mathrm{Cu}(\mathrm{In}, \mathrm{Ga}) \mathrm{Se}_{2}$, for instance) have already been performed in a variety of aqueous electrolytes covering the whole $\mathrm{pH}$ range in order to understand the electrochemical processes which occur at the semiconducting electrode-liquid interface. . $^{30-40}$

Several irreversible reactions can occur at the surface resulting in degradation of the material. It is known that by polarizing the electrode with anodic potential under light, competitive reactions can occur, resulting in dissolution of the metals as cations, aggregation of elemental sulfur at the surface or formation of soluble oxygenated species. Those reactions can cause significant (photo)corrosion and considerably limit the conversion of solar energy into chemical energy. Moreover, some oxidative photodecomposition reactions of $\mathrm{CuInS}_{2}$ in aqueous acidic solutions are listed in the report of Cattarin et $a l .{ }^{35}$ Thus, at the rest potential or higher anodic potential range applied in this study, several reactions can occur leading to the formation and/or the presence of several chemical species such as covellite $(\mathrm{CuS})$, chalcocite $\left(\mathrm{Cu}_{2} \mathrm{~S}\right)$, cations $\left(\mathrm{Cu}^{+}, \mathrm{Cu}^{2+}\right.$, and/or $\mathrm{In}^{3+}$ ) or elemental sulfur (S) to name the principal ones. ${ }^{31,34}$ However, the dissolution of metals from the chalcopyrite is slow, even in highly acidic solutions, and successful methods are well-known in leaching copper. ${ }^{\mathbf{4 1 , 4 2}}$ In order to test if any dissolution or photocorrosion process at the semiconductor/electrolyte interface may interfere with the reduction of protons, cyclic voltammetry studies were performed in the dark and under illumination. The absence of reduction and oxidation peaks in the cathodic and anodic regions, respectively, suggests that soluble species like covellite and/or chalcocite (which are involved in the reduction and oxidation processes) are not present or do not exceed negligible amounts in our system. Charge transfer appears therefore not to be dominated by (photo)corrosion even in this aggressive electrolyte. It is therefore assumed that the measured photocurrent density predominantly results from light-induced hydrogen evolution. ${ }^{37,38}$ These observations support the conclusion that polycrystalline $\mathrm{CuInS}_{2}$ thin films can act as a photocathode in a PEC device for water splitting. Thus, the $\mathrm{H}^{+}$protons are photoelectrochemically reduced to hydrogen gas under acidic conditions at cathodic potentials. Moreover, polycrystalline $\mathrm{CuInS}_{2}$ was found to generate cathodic photocurrents at potentials up to $+0.21 \mathrm{~V}$ vs. RHE in $0.1 \mathrm{M} \mathrm{H}_{2} \mathrm{SO}_{4}$ aqueous solution. This onset potential and the measured photocurrent are higher than those of the $\mathrm{Pt} / \mathrm{CuInGaSe}{ }_{2}$ substrate in the same electrolyte as reported by Domen et $a .^{8}$ This result demonstrates that the $\mathrm{CuInS}_{2}$ photoelectrode reveals a more positive onset potential by about $+0.11 \mathrm{~V}$ than the $\mathrm{Pt} / \mathrm{CuInGaSe} \mathrm{I}_{2}$ heterojunction. It is known that the photocurrent onset is related to the kinetics of the electron transfer at the solid-liquid interface. Therefore, our observations provide clear evidence for the improved rate of electron transfer at the interface of the $\mathrm{CuInS}_{2}$ electrode.

With introduction of the $\mathrm{g}-\mathrm{C}_{3} \mathrm{~N}_{4}$ surface film, this onset potential is furthermore shifted to a higher anodic potential by about $+0.15 \mathrm{~V}$ in comparison to the bare semiconducting $\mathrm{CuInS}_{2}$ electrodes as shown in Fig. 7. Therefore, cathodic photocurrents are generated at potentials up to $+0.36 \mathrm{~V}$ relative to the hydrogen redox potential which points to beneficial band alignment between the film and the substrate, i.e. a negative (downward) band bending in the chalcopyrite, corresponding to the difference of the respective work functions. In a recent report, the photoactivity of $\mathrm{g}-\mathrm{C}_{3} \mathrm{~N}_{4} / \mathrm{CuGaSe}_{2}$ composites has been investigated. ${ }^{17}$ In comparison to this heterojunction, the $\mathrm{g}$ $\mathrm{C}_{3} \mathrm{~N}_{4}$ film on the CuInS $\mathrm{S}_{2}$ electrode shows a strong enhancement by a factor $50 .{ }^{17}$ However, in comparison to the bare $\mathrm{CuInS}_{2}$ substrate, the photocurrent response of the heterosystem appears to be reduced by almost $60 \%$. This observation suggests considerable light absorption losses in the $\mathrm{g}-\mathrm{C}_{3} \mathrm{~N}_{4}$ film. Those losses have to be ascribed to the low charge carrier lifetimes in the $\mathrm{g}-\mathrm{C}_{3} \mathrm{~N}_{4}$ film which are discussed further below in more detail. Transfer of electrons, photogenerated in the substrate, is therefore presumably restricted to sites where the $\mathrm{g}-\mathrm{C}_{3} \mathrm{~N}_{4}$ film is ultrathin, reducing thus the effective electrode area and the overall photocurrent density. The films, as investigated here, therefore act as protective surface coverage of the $\mathrm{CuInS}_{2}$ substrate and allow for shifting of the onset potential for hydrogen evolution to more positive values. They limit, however, the conversion efficiency of incident photons to charge carriers.

It is expected that further improvements in film fabrication will help overcome this detrimental side-effect. Dwell time and heating temperature rate, for instance, both play an important 
role in smoothness of the film, adhesion to the substrate and electronic properties. Moreover, deeper insight into the photoactivity of the resulting $\mathrm{g}^{-} \mathrm{C}_{3} \mathrm{~N}_{4}$ films is required and will be gained by wavelength-dependent photoelectrochemical measurements with and without photoresponsive substrates. These studies are underway and will be discussed in a future report. ${ }^{43}$

To examine the stability of the cathodic photocurrent generated by the g- $\mathrm{C}_{3} \mathrm{~N}_{4} / \mathrm{CuInS}_{2}$ composite electrodes, a constant potential of $-0.5 \mathrm{~V} v s$. $\mathrm{Ag} / \mathrm{AgCl}$ was applied. The time course of the photocurrent for $\mathrm{g}^{-} \mathrm{C}_{3} \mathrm{~N}_{4} / \mathrm{CuInS}_{2}$ composite electrodes immersed in $0.1 \mathrm{M} \mathrm{H}_{2} \mathrm{SO}_{4}$ aqueous solution under continuous visible light irradiation of 1 sun is shown in Fig. 8. The inset in Fig. 8 depicts the magnification of the change in the photocurrent between 0 and $240 \mathrm{~min}$. The composite electrode was first measured in the dark during the first 5 min and then the electrode was illuminated continuously by visible light $(\lambda>$ $400 \mathrm{~nm}$ ) for $22 \mathrm{~h}$. The cathodic photocurrent increased constantly for about $3 \mathrm{~h}$ to reach about $50 \mu \mathrm{A} \mathrm{cm} \mathrm{c}^{-2}$ and then kept constant at an almost steady value for more than $19 \mathrm{~h}$. After $22 \mathrm{~h}$ the light was turned off to confirm that the observed current was light-induced. The increase of the photocurrent during the first $3 \mathrm{~h}$ is probably arising from the time needed for the acidic solution to remove remnant segregated materials from the surface, which presents defect surface states and acts as surface recombination centers of photo-generated electronhole pairs, as also reported for another system (InGaN electrode). ${ }^{44}$ After this first period of time, the heterostructure system $\left(\mathrm{g}-\mathrm{C}_{3} \mathrm{~N}_{4} / \mathrm{CuInS}_{2}\right)$ maintains a constant photocurrent value for about $19 \mathrm{~h}$. As pointed out above, no indications were found for cathodic decomposition of the heterostructure. This result indicates, therefore, that our heterostructure system is highly resistant to reductive decomposition, and presents high photocorrosion and degradation resistance under acidic

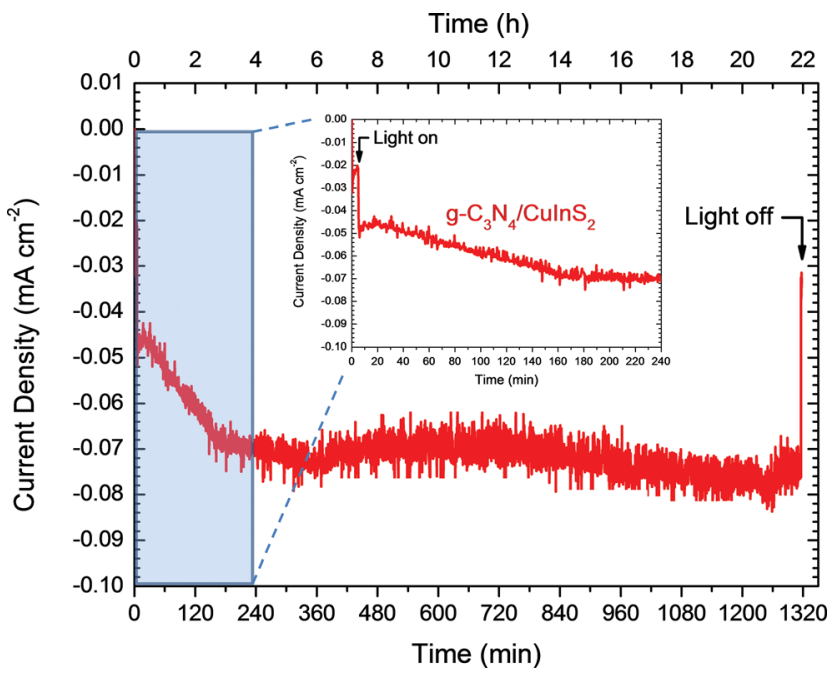

Fig. 8 Time course of the photocurrent for the $\mathrm{g}-\mathrm{C}_{3} \mathrm{~N}_{4} / \mathrm{CulnS} \mathrm{S}_{2}$ electrode in $0.1 \mathrm{M}$ $\mathrm{H}_{2} \mathrm{SO}_{4}$ aqueous solution $(\mathrm{pH} 1)$ under continuous irradiation of visible light $(\lambda>$ $400 \mathrm{~nm}$ ). The potential was kept at $-0.5 \mathrm{~V}$ vs. Ag/ $\mathrm{AgCl}$ reference electrode. The inset shows the magnification of the change in photocurrent for the $\mathrm{g}_{-} \mathrm{C}_{3} \mathrm{~N}_{4} /$ $\mathrm{CuInS}_{2}$ electrode between 0 and $240 \mathrm{~min}$. conditions. Moreover, analysis of the evolved gaseous products by an in-line system mass spectrometer confirmed the evolution of $\mathrm{H}_{2}$ and $\mathrm{O}_{2}{ }^{45}$ The results of Fig. 8 are therefore interpreted as proof for the long-term stability of the photocathode. This stability is first and foremost attributed to the presence of the polymeric $\mathrm{g}-\mathrm{C}_{3} \mathrm{~N}_{4}$ network that allows - to a limited extent transfer of photogenerated electrons from the substrate to the electrolyte while direct contact of the chalcopyrite to the acidic solution is suppressed.

Finally, the electronic and optical properties of the investigated heterostructure are discussed in more detail. Chalcopyrites are known to show high solar-to-electric conversion efficiencies, which are attributed to strong optical absorption (due to the direct bandgap) and their exceptional carrier transport properties. Herein, $\mathrm{CuInS}_{2}$ electrodes with a bandgap energy of $1.5 \mathrm{~V}$ closely match the visible part of the solar spectrum. Polymeric $\mathrm{g}-\mathrm{C}_{3} \mathrm{~N}_{4}$ with its bandgap of approximately $2.7 \mathrm{eV}$ can solely absorb effectively a moderate fraction of the solar spectrum. In practice, the operating point of an effective PEC semiconductor film (here, the heterostructure composite device) depends on the energetics (band edge positions) and electrode kinetics (overpotentials). In the photocathode configuration, a proper band edge alignment is critical to minimize the required additional voltage bias from underlying junctions to achieve high-efficiency PEC water splitting.

In Fig. 9, an idealized energy band diagram of the heterostructure g- $\mathrm{C}_{3} \mathrm{~N}_{4} / \mathrm{CuInS}_{2}$ composite is proposed. The band edge alignment of the composite photocathode is based on the XPS/ UPS analysis (see Fig. 4). The electrochemical and the absolute scale of both the hydrogen reduction potential, $\mu_{\mathrm{e}}{ }^{\mathrm{H}+\mathrm{H}_{2}}$, and the water oxidation potential, $\mu_{\mathrm{e}}{ }^{\mathrm{O}_{2} / \mathrm{H}_{2} \mathrm{O}}$, are also presented on the right side. From the literature, $\mu_{\mathrm{e}}{ }^{\mathrm{H}+/ \mathrm{H}_{2}}$ is referred to the vacuum level, $E_{\mathrm{vac}}$, with values in the range between 4.4 and $4.7 \mathrm{eV}^{.6-49}$ Here, $\mu_{\mathrm{e}}{ }^{\mathrm{H} / \mathrm{H}_{2}}$ was chosen to be equal to $4.6 \mathrm{eV}$ corresponding to

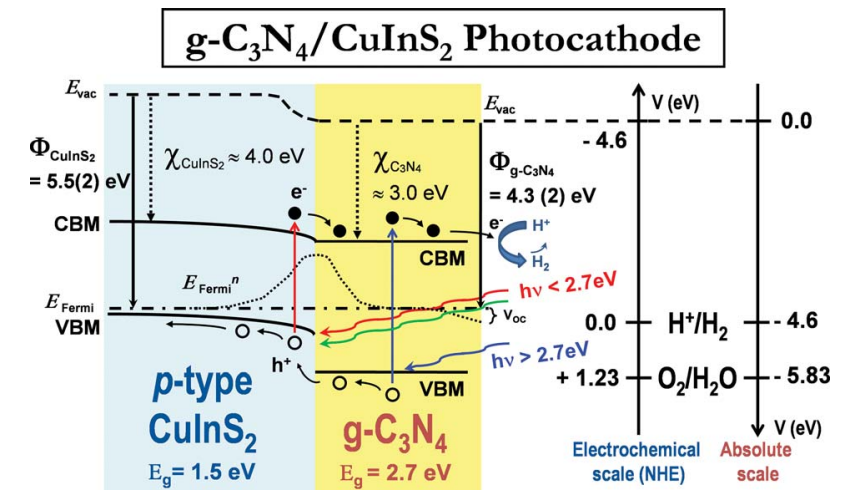

Fig. 9 Proposed energy band diagram of the $\mathrm{g}-\mathrm{C}_{3} \mathrm{~N}_{4}-\mathrm{Culn \textrm {S } _ { 2 }}$ heterosystem. The respective work functions, $\Phi$, electron affinities, $\chi$, and the resulting band-edge alignments are shown as deduced from the XPS/UPS analysis. The electrochemical and the absolute scale are given on the right side. The hydrogen redox potential is

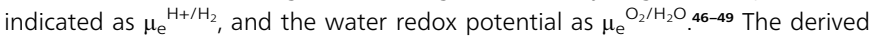
energetic position of the CBM of $\sim 3 \mathrm{eV}$ - i.e. the electron affinity, $\chi$ - is negative versus $\mu_{\mathrm{e}}{ }^{\mathrm{H+} / \mathrm{H}_{2}}$, which allows the heterostructure composite electrode to operate as the hydrogen evolving photocathode with reduced overpotentials. $E_{\text {Fermi }}{ }^{n}$ denotes the quasi-Fermi level for excess minority electrons and $V_{O C}$ represents the open circuit voltage under illumination. 
the redox potential of the normal hydrogen electrode, NHE. For the heterostructure based $\mathrm{g}-\mathrm{C}_{3} \mathrm{~N}_{4}$ films, the electron affinity has to be smaller than $\mu_{\mathrm{e}}{ }^{\mathrm{H}+\mathrm{H}_{2}}$ in order to efficiently transfer electrons to protons in solution. Our very recent photoemission results of $\mathrm{g}-\mathrm{C}_{3} \mathrm{~N}_{4}$ films, covered with a thin surface oxide, suggest a work function of $\Phi=4.3 \pm 0.1 \mathrm{eV}$ after photoelectrochemical operation and an energetic distance between the valence band maximum, $E_{\mathrm{VBM}}$, and the Fermi level, $E_{\mathrm{F}}$, of $\Delta_{\mathrm{VBM}-\mathrm{EF}}=1.4 \pm 0.3 \mathrm{eV}$. Considering the band gap energy of g$\mathrm{C}_{3} \mathrm{~N}_{4}$ films, $E_{\mathrm{g}}=2.7 \pm 0.1 \mathrm{eV}$, the electron affinity of $\mathrm{g}-\mathrm{C}_{3} \mathrm{~N}_{4}$ films is deduced to be about $3 \mathrm{eV}$ relative to $E_{\mathrm{vac}}$. These results are indicative of an intrinsic $g-\mathrm{C}_{3} \mathrm{~N}_{4}$ semiconductor and a conduction band maximum, $\mathrm{E}_{\mathrm{CBM}}$, of $\mathrm{g}-\mathrm{C}_{3} \mathrm{~N}_{4}$ energetically positioned above the hydrogen redox potential $\mu_{\mathrm{e}}{ }^{\mathrm{H}+/ \mathrm{H}_{2}}$.

According to the different work functions, $\Phi_{\mathrm{g} \text {-C3N4 }}$ and $\Phi_{\text {CuIns2 }}$, of the surface film and substrate, Fermi-level equilibration takes place upon contact of the two materials, g- $\mathrm{C}_{3} \mathrm{~N}_{4}$ and $\mathrm{CuInS}_{2}$. Due to the much higher conductivity of the substrate, a space charge region is mainly created in the chalcopyrite as shown in Fig. 9. The strength of the resulting band bending can be approximately deduced from the difference $\Delta \Phi$ $=\Phi_{\mathrm{g} \text {-C3N4}}-\Phi_{\text {CuIns2. }}$ Under illumination, separation of photogenerated carriers occurs at the interface of the heterostructure, accelerating thereby electrons towards the solid-liquid interface and holes towards the front-contact. With its protective function, the $\mathrm{g}-\mathrm{C}_{3} \mathrm{~N}_{4}$ film additionally suppresses defects formation at the $\mathrm{CuInS}$ interface. At sites where the $\mathrm{g}-\mathrm{C}_{3} \mathrm{~N}_{4}$ film is thin enough, interface recombination is reduced and electron transfer towards the electrolyte is enhanced. Therefore, g- $\mathrm{C}_{3} \mathrm{~N}_{4}$ films seem to act mostly as passivation layers in the study presented here and improve the stability of the composite electrode (see Fig. 8) by reducing the surface and interface states, which play an important role in photocurrent losses due to recombination processes.

In the case of the bare $\mathrm{CuInS}_{2}$ electrode with a bandgap energy of $1.5 \mathrm{~V}$, light with wavelength energy below $830 \mathrm{~nm}$ is absorbed. In contrast, only a moderate fraction of the solar spectrum can be effectively absorbed by the $\mathrm{g}-\mathrm{C}_{3} \mathrm{~N}_{4}$ film due to its bandgap of approximately $2.7 \mathrm{eV}$. Moreover, it is known that a bandgap between 2.5 and $2.8 \mathrm{eV}$ of the most common films used for PEC could limit achievable photocurrents. Therefore, it is clear that the CuInS 2 electrode beneath the $\mathrm{g}-\mathrm{C}_{3} \mathrm{~N}_{4}$ film can only absorb photons within the wavelength range of 460-830 $\mathrm{nm}$ (i.e., $1.5 \mathrm{eV}<h \nu<2.7 \mathrm{eV}$ ), i.e. below the bandgap of the polymeric carbon nitride. Due to the short charge carrier lifetimes in the $\mathrm{g}-\mathrm{C}_{3} \mathrm{~N}_{4}$ film, photoelectrons excited by light with wavelengths $>460 \mathrm{~nm}$ can only contribute to the photocurrent response where the film thickness is in the nm range. Otherwise, recombination takes place and attenuates the measured photocurrent density. ${ }^{50,51}$ Transient photoluminescence studies on $\mathrm{g}-\mathrm{C}_{3} \mathrm{~N}_{4}$ revealed recently an estimated value of the charge carrier lifetimes of the order of 3 ns due to charge localization and native defects. ${ }^{52}$ Therefore, the polymeric carbon nitride structure is characterized by short minority carrier diffusion lengths $(<2 \mathrm{~nm})$ that prevent efficient charge transfer in thick films. The thickness of the $\mathrm{g}-\mathrm{C}_{3} \mathrm{~N}_{4}$ film is therefore the key issue in designing an efficient heterostructured photocathode. For this reason, controlling the film thickness will be of major importance for future device development. It is envisaged that those ultrathin films can simultaneously fulfill the requirements as a protective layer and as an electronically active layer without limiting the transfer of photoinduced electrons towards the electrolyte.

\section{Conclusions}

For the first time, we have provided clear evidence for the beneficial role of polymeric carbon nitride films, $\mathrm{g}-\mathrm{C}_{3} \mathrm{~N}_{4}$, as a protective layer on $\mathrm{CuInS}_{2}$ photocathodes. The photoelectrochemical performance of the $\mathrm{g}-\mathrm{C}_{3} \mathrm{~N}_{4}$ film/CuInS $\mathrm{S}_{2}$ heterosystem under an illumination of 1 sun was observed to stably operate for $22 \mathrm{~h}$ in acidic electrolytes. The conversion of solar energy to chemical energy could be confirmed by mass spectrometric detection of evolving $\mathrm{H}_{2}$ and $\mathrm{O}_{2}$. Extensive analysis of photoelectron spectroscopy results was used to devise a band diagram of the junction with respect to the absolute as well as electrochemical scale. From this analysis it follows that the g$\mathrm{C}_{3} \mathrm{~N}_{4}$ film assumes also an important electronic role upon contact formation with the $\mathrm{CuInS}_{2}$ substrate. Fermi-level equilibration leads to a downward band bending in the substrate and, correspondingly, to a more positive onset potential for hydrogen evolution than observed for the bare substrate. On the other hand, the rate of electron transfer towards the electrolyte is limited by short charge carrier lifetimes in thicker regions of the $\mathrm{g}-\mathrm{C}_{3} \mathrm{~N}_{4}$ film. Future developments will therefore focus on the design of ultrathin coverage with a g- $\mathrm{C}_{3} \mathrm{~N}_{4}$ film in order to improve the overall photocurrent output as well.

\section{Acknowledgements}

The authors would like to thank C. Ferber for the KCN etching of the CuInS 2 electrodes and J. Albert for providing the SEM images. Financial support granted by the BMBF excellence cluster project "Light2Hydrogen" (grant no. 03IS2071F) is gratefully acknowledged.

\section{References}

1 K. Maeda and K. Domen, J. Phys. Chem. C, 2007, 111, 78517861.

2 M. G. Walter, E. L. Warren, J. R. McKone, S. W. Boettcher, Q. X. Mi, E. A. Santori and N. S. Lewis, Chem. Rev., 2010, 110, 6446-6473.

3 R. Klenk, J. Klaer, R. Scheer, M. C. Lux-Steiner, I. Luck, N. Meyer and U. Ruhle, Thin Solid Films, 2005, 480, 509-514.

4 J. Haarstrich, H. Metzner, M. Oertel, C. Ronning, T. Rissom, C. A. Kaufmann, T. Unold, H. W. Schock, J. Windeln, W. Mannstadt and E. Rudigier-Voigt, Sol. Energy Mater. Sol. Cells, 2011, 95, 1028-1030.

5 J. Klaer, I. Luck, A. Boden, R. Klenk, I. G. Perez and R. Scheer, Thin Solid Films, 2003, 431, 534-537.

6 M. Rusu, S. Wiesner, R. Wurz, S. Lehmann, S. DokaYamigno, A. Meeder, D. F. Marron, M. Bar, V. Koteski, 
H. E. Mahnke, E. Arushanov, J. Beckmann, K. Hohn, W. Fritsch, W. Bohne, P. Schubert-Bischoff, M. Heuken, A. Jager-Waldau, A. Rumberg and T. Schedel-Niedrig, Sol. Energy Mater. Sol. Cells, 2011, 95, 1555-1580.

7 See for example http://www.wuerth-solar.de/ and http:// www.soltecture.de/.

8 D. Yokoyama, T. Minegishi, K. Maeda, M. Katayama, J. Kubota, A. Yamada, M. Konagai and K. Domen, Electrochem. Commun., 2010, 12, 851-853.

9 K. Siemer, J. Klaer, I. Luck, J. Bruns, R. Klenk and D. Braunig, Sol. Energy Mater. Sol. Cells, 2001, 67, 159-166.

10 F. Goettmann, A. Fischer, M. Antonietti and A. Thomas, Angew. Chem., Int. Ed., 2006, 45, 4467-4471.

11 X. C. Wang, K. Maeda, A. Thomas, K. Takanabe, G. Xin, J. M. Carlsson, K. Domen and M. Antonietti, Nat. Mater., 2009, 8, 76-80.

12 T. Tyborski, C. Merschjann, S. Orthmann, F. Yang, M. C. LuxSteiner and T. Schedel-Niedrig, J. Phys.: Condens. Matter, 2012, 24, 162201.

13 Y. Wang, X. Wang and M. Antonietti, Angew. Chem., Int. Ed., 2012, 51, 68-89.

14 Y. Zheng, J. Liu, J. Liang, M. Jaroniec and S. Z. Qiao, Energy Environ. Sci., 2012, 5, 6717-6731.

15 K. Maeda, X. C. Wang, Y. Nishihara, D. L. Lu, M. Antonietti and K. Domen, J. Phys. Chem. C, 2009, 113, 49404947.

16 A. Thomas, A. Fischer, F. Goettmann, M. Antonietti, J. O. Muller, R. Schlogl and J. M. Carlsson, J. Mater. Chem., 2008, 18, 4893-4908.

17 F. Yang, M. Lublow, S. Orthmann, C. Merschjann, T. Tyborski, M. Rusu, S. Kubala, A. Thomas, R. Arrigo, M. Hävecker and T. Schedel-Niedrig, ChemSusChem, 2012, 5, 1227-1232.

18 J. R. Pels, F. Kapteijn, J. A. Moulijn, Q. Zhu and K. M. Thomas, Carbon, 1995, 33, 1641-1653.

19 M. J. Bojdys, J. O. Muller, M. Antonietti and A. Thomas, Chem.-Eur. J., 2008, 14, 8177-8182.

20 S. M. Lyth, Y. Nabae, S. Moriya, S. Kuroki, M. Kakimoto, J. Ozaki and S. Miyata, J. Phys. Chem. C, 2009, 113, 2014820151.

21 Q. X. Guo, Y. Xie, X. J. Wang, S. C. Lv, T. Hou and X. M. Liu, Chem. Phys. Lett., 2003, 380, 84-87.

22 R. J. Nemanich and S. A. Solin, Phys. Rev. B: Condens. Matter Mater. Phys., 1979, 20, 392-401.

23 A. C. Ferrari, S. E. Rodil and J. Robertson, Phys. Rev. B: Condens. Matter Mater. Phys., 2003, 67, 155306.

24 V. N. Khabashesku, J. L. Zimmerman and J. L. Margrave, Chem. Mater., 2000, 12, 3264-3270.

25 J. L. Zimmerman, R. Williams, V. N. Khabashesku and J. L. Margrave, Nano Lett., 2001, 1, 731-734.

26 M. Kawaguchi and K. Nozaki, Chem. Mater., 1995, 7, 257264.

27 E. G. Gillan, Chem. Mater., 2000, 12, 3906-3912.
28 J. H. Kaufman, S. Metin and D. D. Saperstein, Phys. Rev. B: Condens. Matter Mater. Phys., 1989, 39, 13053-13060.

29 Y. Wang, D. C. Alsmeyer and R. L. McCreery, Chem. Mater., 1990, 2, 557-563.

30 M. Robbins, K. J. Bachmann, V. G. Lambrecht, F. A. Thiel, J. Thomson, R. G. Vadimsky, S. Menezes, A. Heller and B. Miller, J. Electrochem. Soc., 1978, 125, C159-C160.

31 T. Biegler and D. A. Swift, J. Appl. Electrochem., 1979, 9, 545554.

32 H. J. Lewerenz, H. Goslowsky and F. A. Thiel, Sol. Energy Mater., 1983, 9, 159-166.

33 G. W. Warren, H. J. Sohn, M. E. Wadsworth and T. G. Wang, Hydrometallurgy, 1985, 14, 133-149.

34 R. I. Holliday and W. R. Richmond, J. Electroanal. Chem., 1990, 288, 83-98.

35 S. Cattarin, P. Guerriero, N. Dietz and H. J. Lewerenz, Electrochim. Acta, 1995, 40, 1041-1049.

36 C. Gomez, M. Figueroa, J. Munoz, M. L. Blazquez and A. Ballester, Hydrometallurgy, 1996, 43, 331-344.

37 E. M. Arce and I. González, Int. J. Miner. Process., 2002, 67, 17-28.

38 R. C. Valderrama, P. J. Sebastian, M. Miranda-Hernandez, J. P. Enriquez and S. A. Gamboa, J. Photochem. Photobiol., A, 2004, 168, 75-80.

39 B. Marsen, B. Cole and E. L. Miller, Sol. Energy Mater. Sol. Cells, 2008, 92, 1054-1058.

40 J. Kaneshiro, N. Gaillard, R. Rocheleau and E. Miller, Sol. Energy Mater. Sol. Cells, 2010, 94, 12-16.

41 T. Biegler and D. A. Swift, Hydrometallurgy, 1977, 2, 335-349.

42 A. J. Parker, R. L. Paul and G. P. Power, J. Electroanal. Chem., 1981, 118, 305-316.

43 F. Yang, V. Kuznietsov, C. Merschjann, M. Rusu and T. Schedel-Niedrig, in preparation.

44 M. X. Li, W. J. Luo, B. Liu, X. Zhao, Z. S. Li, D. J. Chen, T. Yu, Z. L. Xie, R. Zhang and Z. G. Zou, Appl. Phys. Lett., 2011, 99, 112108.

45 F. Yang, M. Pogrzeba, V. Kuznietsov, C. Merschjann, A. Steigert, M. Lublow, C. A. Kaufmann and T. SchedelNiedrig, in preparation.

46 R. Gomer and G. Tryson, J. Chem. Phys., 1977, 66, 4413-4424.

47 W. N. Hansen and D. M. Kolb, J. Electroanal. Chem., 1979, 100, 493-500.

48 S. Trasatti, J. Electroanal. Chem., 1986, 209, 417-428.

49 H. Reiss and A. Heller, J. Phys. Chem., 1985, 89, 4207-4213.

50 X. Wang, K. Maeda, X. Chen, K. Takanabe, K. Domen, Y. Hou, X. Fu and M. Antonietti, J. Am. Chem. Soc., 2009, 131, 1680-1681.

51 Y. Zhang, T. Mori, J. Ye and M. Antonietti, J. Am. Chem. Soc., 2010, 132, 6294-6295.

52 C. Merschjann, T. Tyborski, S. Orthmann, F. Yang, K. Schwarzburg, M. Lublow, M. C. Lux-Steiner and T. Schedel-Niedrig, Phys. Rev. B: Condens. Matter Mater. Phys., in press. 